\title{
電話送話器用炭素粉の感度
}

\section{久保田精 司* \\ Study on the Response of Granular Carbon for Use of Telephone Transmitter}

by Seiji Kubota

(Fundamental Research Laboratory, Nippon Electric Company Ltd, Kawasaki, Japan)

Various kinds of carbon powders for telephone transmitter use having apparent specific resistivity in the range $30 \sim 500 \Omega$ are prepared from Hongê anthracite. The parameters varied in the preparation are (i) particle size of the anthracite, (ii) temperature and time of the roasting and (iii) admixture of organic vapor or $\mathrm{CO}_{2}$ in the roasting atmosphere. One of the samples which seems to be suitable for telephone transmitter is life tested under severe conditions, viz. oxidation at high temperature, immersion in water, adsorption of water. The influences of electrical and mechanical shocks are also studied. These factors give rise to appreciable increase of apparent resistivity of carbon powders and also to deterioration in the response expressed in efficiency.

The electric properties, microscopic features and the angle of repose of the life tested samples are compared with those of the original carbon powders. From the results it is concluded that the response of the powders is decreased with the increases of (i) the defects in the surfaces of the powders caused by mechanical shocks, (ii) surface roughness caused by oxidation and (iii) adhesion of soot to the surfaces. The response also deteriorates due to the existance of surface layers composed of adsorbed water, of oxides of metals such as iron and of other contaminations.

\section{1. 緒言}

電話送話器用炭素粉は直流電圧印加の下で, 入力音声 に応じて電気的出力を発生するものであるから，単位直 流入力に対する感度, すなわち能率感度1)の大小は炭素 粉の品質を表わす重要な要素となる。

先に炭素粉表面の污れが能率感度に大きな影響を与え ることを報告 2)したが，さらに製造および使用面からみ た諸因子と能率感度との関係を明らかにすることが出来 たので報告する。

\section{2. 実験}

\section{1 試料}

測定試料としては製造条件および燒成後の処理条件を 種々変えたものを次のように準備した。

（1）基準試料：処理条件の感度に対する影響をしら ベる基準試料はホンゲイ無煙炭を選別，粉砕，節別，水 洗, 酸洗等の行程を経て 50 80 メッシュの原料炭粉と し，これを内径 $50 \mathrm{~mm}$ の石英管を有する電気炉中で， $700^{\circ} \mathrm{C}$ の変成炉を通して変成した都市ガスを 150 ～170 c.c/分の割合で流しながら $980^{\circ} \mathrm{C}$ で 3 時間焼成した。

\footnotetext{
* 日本電気 (株) 基礎研研所
}

（2）抵抗值の違う炭素粉: 基準試料と同じ方法で最 高保持温度だけ $700^{\circ} \mathrm{C} よ り 1150^{\circ} \mathrm{C}$ まで変えて煳成， 抵抗值の違う試料とした。

（3）粒度の違う炭素粉：原料炭の 粒度を $10 \sim 30$, 30〜60, 60〜100, 100〜150, 150〜200 メッシュとし, 基準試料と同じ烽成法で試作した。

（4）有機物蒸気を混入燒成した炭素粉：基準燒成方 法によるが，最高保持温度で 3 時間保持のときだ 700 ${ }^{\circ} \mathrm{C}$ 変成後のガスをベンゾール液中を通して有機物蒸気 を含ませ，これを烇成雾囲気とした。ベンゾールの外に アセトン, 四壏化炭素, エチルアルコールについても実 験し，またベンゾールの液を通す時間を 30 分に短縮す るなど，いろいろの試料をつくった。

（5）炭酸ガスを混合焼成した炭素粉：最高温度保持 中炭酸ガスを $50 \mathrm{c} . \mathrm{c} /$ 分の割合で通して都市ガスと炭酸 ガスの混合雾囲気で燒成した。

（6）焼成時間の違う炭素粉：最高温度保持時間だけ $1,3,5,8,10$ 時間に変えた。

（7）污れの違う炭素粉：炭素粉は燒成方法により, 特に着炭成分を含むガスを使用すると炭素粉の表面へ煤 状の微粉が付着し, この炭素粉をアルコール液に浸漬振 燳すると液が濁ることがある。その程度の違う炭素粉を 
感度测定用として準備した。

（8）酸化した炭素粉: 一定量の炭素粉を環状炉に入 れ, 両端には緩い遮蔽板だけ入れ, 空気が流通出来る状 態で $200 \sim 900^{\circ} \mathrm{C}$ で 30 分加熱し, 灰化した部分は取除 き測定試料とした。

（9）機械的，電気的衝撃を与えた炭素粉：炭素粉は 機械的衝撃に極めて弱く抵抗上昇する。機械的衝撃の与 え方としては，第一に 120 メッュの標準篩に炭素粉を $5 \mathrm{~g}$ 入れ，1 秒間に 1 振動の割合で 1 5 分間の衝撃を 与えた。また第二の方法としては劣化試験機で回転だけ 与えた場合と，電流を重畳した場合につき，1〜20 時間 の衝撃を与えた。

（10）吸湿した炭素粉：炭素粉は主として焼成方法お よび置かれる雾团気によって，その吸湿量がことなる。 本実験では吸湿の影響を明確にするため，吸湿率のやや 大きい炭素粉を使用した。吸湿は湿度の違う雾团気，す なわち乾燥したシリカゲル，硝酸マグネシウムならびに 塩化アンモンの飽和溶液を入れたデシケータ中に大れ， 10,20 時間の 2 種類の吸湿試料をつくった。

（11）浸水した炭素粉：炭素粉 1 c.c を純水 5 c.c に 浸漬し，4 時間加 7 日間経過後濾別し， $110^{\circ} \mathrm{C}$ で 1 時 間乾燥した試料。

\section{2 測 定}

2.1 で準備した試料を感度測定器で感度および抵抗を 測定した。炭素粉の 感度は普通電力感度で示され，20 $\log _{10} \mathrm{e} / \xi \sqrt{r}$ で示される。ここで $\xi$ は可動電極に与え られる変位 $(\mathrm{cm}), \mathrm{e}$ は一定電流を流し変位を与えたと き電極間に誘超する電圧 $(V), r$ はこのときの炭素粉の 抵抗 $(\Omega)$ である。

しかし電力感度では抵抗の違う炭素粉の感度の比較が 出来ないので, 単位変位, 単位供給電力によって得られ る交流の最大出力の 4 倍の $10 \mathrm{log}$ をとった量，すなわ ち $20 \log _{10} \mathrm{e} / \xi \sqrt{r}-10 \log _{10} \mathrm{~W}$ であらわす方法が能率と して提案されている ${ }^{1)}$ 。この方法では抵抗の違う炭素粉 の品質が比較出来るので，筆者もこの方法を採用した。 また感度の襄付の為の実験として顕微鏡観察を初めとす る若干の測定を加えた。

\section{3. 実験結果並に考察}

3. 1 抵抗值の影響: 抵抗值の違う炭素粉の感度掞よ び抵抗を測定し，感度は電力感度と能率感度の双方であ らわし，これを Fig. 1 に示した。図より電力感度は抵 抗值の大きい試料程大きいが，能率感度で示すと略々一 定值となり，同種類の抵抗の違う炭素粉の能率感度は测 定誤差程度で略々一定と見做すことができる。

3. 2 粒度の影響 : 粒度との関係を Fig. 2 に示し

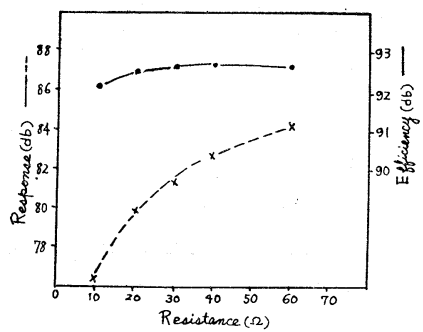

Fig. 1. Resistance $\sim$ Response $\sim$ Efficiency

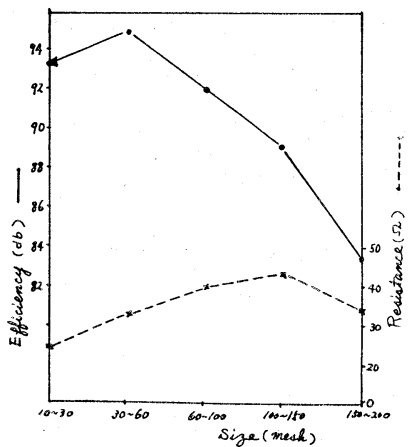

Fig. 2. Effect of Granular Size on Efficiency.

た。

図より粒度が粗なもの程能率感度が大きい。10〜30 メッシュで若干悪くなっているが，これは岑奖室の割に 粒度が粗で，与えられる変位に対して円洲な变化ができ ないためと考える。細かくなると粉末は一般に粘着性を 増し, 粉体群として働らき，また個々の粒子の摩擦抵抗 も増大するため感度が低下すると考えられる。特に 150 〜200メッシュで抵抗が低く感度が悪いのはこの影樂が 顕著にあらわれたものと思考する。この関係を知る一手 段として粒度と静止角の関係を測定しこれを Table 1. に示す。

Table 1. Relation between Ǵranular Size and Angle of Repose.

\begin{tabular}{l|l|l|l|l|l}
\hline \hline Size & $10 \sim 30$ & $30 \sim 60$ & $60 \sim 100$ & $100 \sim 150$ & $150 \sim 200$ \\
\hline$\theta$ & $16^{\circ} 10^{\prime}$ & $21^{\circ} 30^{\prime}$ & $25^{\circ} 35^{\prime}$ & $27^{\circ} 51^{\prime}$ & $31^{\circ} 31^{\prime}$ \\
\hline
\end{tabular}

すなわち粒度の細かいもの程静止角が大きく，摩擦抵 抗が大きいことを示しており，これより感度が低下する ことも了解される。

3. 3 有機物蒸気混入焼成の影響: 変成都市ガスにべ ンゾール等の蒸気を含ませた霉囲気で焼成した炭素粉の 感度の測定結果を Table 2 に示した。

これらの試料のうちベンゾール混入のものは外観は銀 白色を呈しており，着炭の進んでいることが推察出来 
Table 2. Effect of Organic Vapor on Efficiency

\begin{tabular}{c|c|c|c|c|c}
\hline \hline & Benzol & Aceton & $\begin{array}{c}\text { Carbon } \\
\text { Tetra- } \\
\text { chloride }\end{array}$ & $\begin{array}{c}\text { Ethyl } \\
\text { Alcohol }\end{array}$ & $\begin{array}{c}\text { Benzol } \\
\text { (Short } \\
\text { Time) }\end{array}$ \\
\hline $\mathrm{db}$ & 84.1 & 84.2 & 89.1 & 90.9 & 90.9 \\
\hline
\end{tabular}

る感度と光沢度の関係は本実験による着炭試料では光沢 の大なるもの程感度低下が大である。この低下の原因は 後で述べる污れの影響と考える。

3. 4 炭酸ガス混入焼成の影響: 酸化性ガスである炭 酸ガスを混入した雱囲気で焼成した炭素粉は予想された ことであるが，能率感度 $86 \mathrm{db}$ であり，その吸湿率は約 $10 \%$ となり，相当酸化されていることが明らかである。 従って感度の面から見て酸化性ガスの混入は好ましくな いことが明らかとなった。

3. 5 烊成時間の影響: 基準焼成法で最高温度保持時 間を変えた試料の能率感度を Table 3 に示した。

Table 3. Effect of Roasting Time on Efficiency.

\begin{tabular}{r|c|c|c|c|c}
\hline \hline $\mathrm{Hr}$ & 1 & 3 & 5 & 8 & 10 \\
\hline $\mathrm{db}$ & 91.2 & 91.6 & 89.7 & 89.2 & 89.0 \\
\hline
\end{tabular}

時間が長くなると抵抗がさがると共に能率感度が低下 している。この場合の感度低下は主として炭素粉表面の 污れの増大の影響と考える。従って必要以上の長時間焼 成は思わしくない。

3. 6 污れの影響: この関係については前報3) で述べ たので詳細は省略するが，污れの大きいものは感度が低 く，摩擦抵抗も大きい。污机を除くと感度は向上する。

3. 7 酸化の影響: 空気中で酸化させた試料の酸化温 度と抵抗及び能率感度との関係を Fig. 3 に示す。

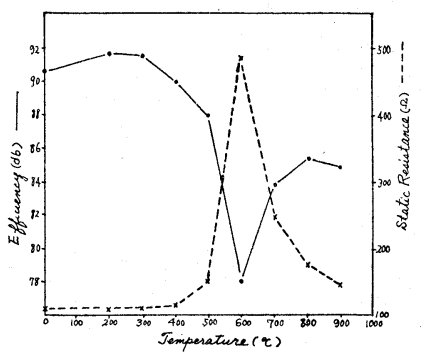

Fig. 3. Effect of Oxidation on Efficiency.

図より抵抗值は $600^{\circ} \mathrm{C}$ 付近で最大となり，その上下 で低く出ている。能率感度は抵抗值が高くなったものほ ど低く出ており, 劣化の進んだもの程感度低下が大きい ことを示している。Photo. 1 (a) は燒成後未処理，(b) は $600^{\circ} \mathrm{C}$ 酸化，(c) は $900^{\circ} \mathrm{C}$ 酸化炭素粉の顕微鏡写真
である。この写真で $600^{\circ} \mathrm{C}$ 酸化のものは表面が非常に 凹凸を增し，光沢が失なわれている。このことから接触 角の增大，感度低下，抵抗增大現象が明らかに推定され る。これに対し $900^{\circ} \mathrm{C}$ 酸化のものは灰化したものもあ るがその他のものはの $600^{\circ} \mathrm{C}$ ものり光沢, 形共によ い。これらの結果からして炭素粉が空気中で酸化される ときは酸化温度によりその表面状態が違った状態とな り, $600^{\circ} \mathrm{C}$ 付近の酸化が最も抵抗の増大を来し, 趡って 感度低下も最も大きいことが明らかになった。

3. 8 機械的衝撃の影響: 節による衝撃で作用させた 時間と抵抗及び能率感度との関係を Fig. 4.劣化試験機 による同じ関係を Fig. 5 に示す。節による衝撃は非常 に抵抗を増大せしめ, その上昇割合に此例して能率感度 は低下する。ただし劣化試験機による衝撃では節による 場合より衝撃が緩かな為か抵抗上昇がすくなく感度低下 もすくない。何れにせよ炭素粉は機械的衝撃に非常に弱 く, 抵抗上昇を来しその上昇程度に応じて感度が低下す ることが明らかになった。

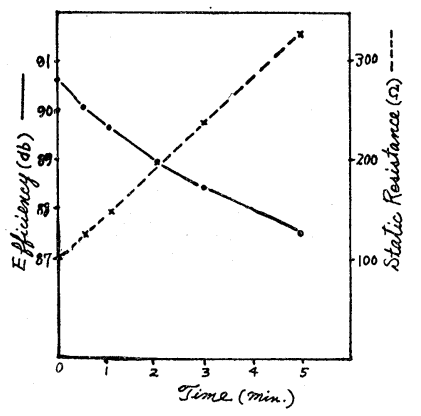

Fig. 4. Effect of mechanical Shock on Efficiency

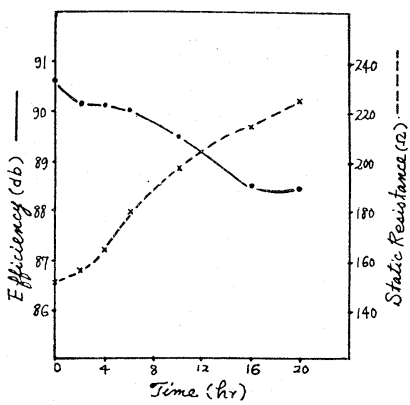

Fig. 5. Effectof Mechanical Shock by Test Machine on Efficiency

3. 9 機械的, 電気的衝撃重畳の影響: 前項の劣化試 験機による機械的衝撃に電流を添加したときの時間と抵 抗抢よび感度との関係を Fig. 6 に示した。この場合の 抵抗上昇は大きく，感度も機械的衝撃のみの場合の $2 \mathrm{db}$ に対し $3.5 \mathrm{db}$ の低下で電流により非常に促進されてい 
ることがわかる。また感度测定に際し 16 時問以上の処 理を行なった試料は测定中抵扰值抢よび感度に不安定性 が認められ，表面が相当劣化が進んでいることを示し t。

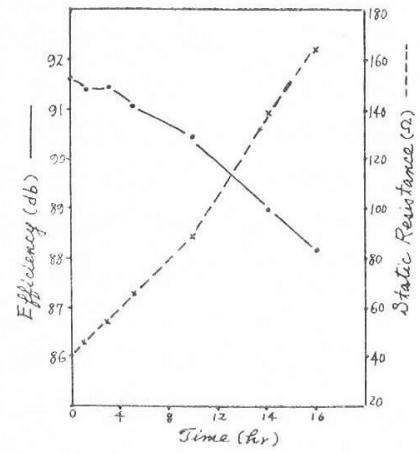

Fig. 6 Effects of Mehanical and Electrical Schocks by Test Machine on Efficiency.

3. 10 吸湿の影響: 2.1（10）により準備した吸澋量 の違う炭素粉の能率感度を測定した結果老 Fig. 7 に示 す。図中感度の指示点に示した数字は吸湿水分量 $(\%)$ であり，吸湿水分量が多くなるに従い能率感度は低下し ている。これは水分によって粒体同志が付着し合い，粘 体は大きな塊の集合となって摩察が大きくなるからであ $3^{3)}$ 。

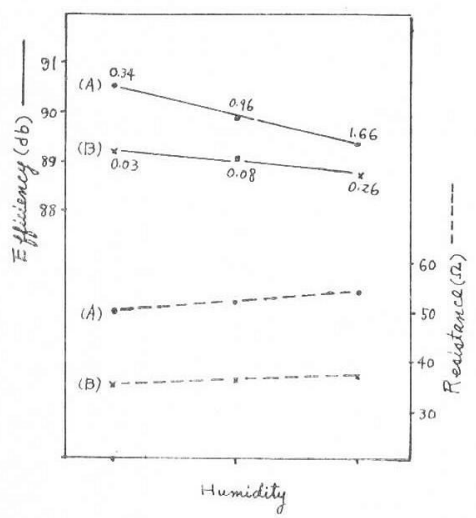

Fig. 7 Effect of Absorbed Water on Efficiency

3.11 漫水の影響: 水汇浸溑した炭素粉在 滤過趹燥した炭素粉の能率感度と浸漬時間の関 係を Fig. 9 に示した。図より浸漬時間の長い 試料程抵抗が増大し，それと共に感度が低下し ているが，抵抗增大の制合に感度の低下はすく なく 1 週間で約 $1.5 \mathrm{db}$ であった。浸水による 抵抗上昇は不純物の付着による影響が大で組織
の破壤はすくないため極端な低下は超らない。しかしこ の場合斥表面の劣化の進展と共に感度低下省来している ことは他の場合と同じである。

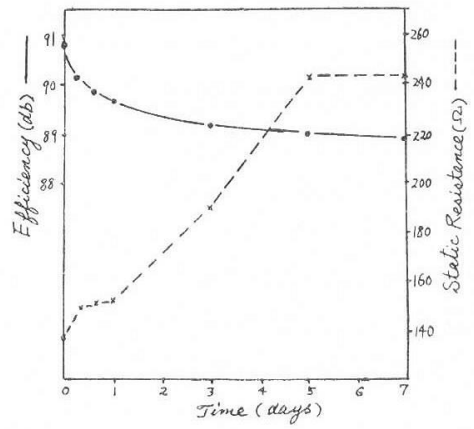

Fig. 8. Effect of Immersion in Water on Efficiency.

3. 12 顕微鏡による表百観祭： 3.7 ては酸化した岸 贲粉の表面の顕微鏡与具を示したか，別に感度低下の大

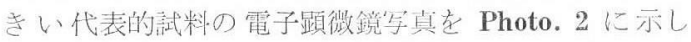
た。（a）はベンゾール蒸気老含ませて㹸成した宸素粉の 表面て着炭が相当進み， 凸起状の多の生したり，煤状 のものがついていのが認められる。写真では嗰らかて ないが多量に着炭すると樹枝状または糸状に付着してい るのが認められだ。（b）は炭酸ガスを混人した需囲匃 で焼成したもので Photo. 1 の（b)(c) に相当するもの で，酸化のため極端に円凸を堌している。また（c）は 外国製の炭素粉て感度が極端に悪いものであるが，その 表面は酸化した試料に似て凹円が大きく，それに加えて 表面の付着物も諗められるので感度が極端に悪いのであ 万弓。

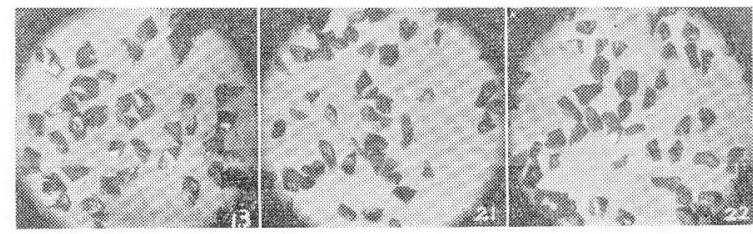
(a) Original.
(b) $600^{\circ} \mathrm{C}$
(c) $900^{\circ} \mathrm{C}$

Photo. 1 Micrographs of Oxidized Carbon $(\times 50)$

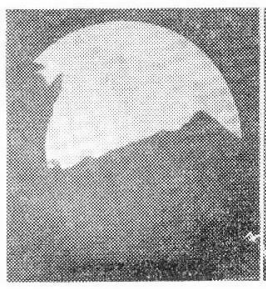

(a) $\mathrm{C}_{6} \mathrm{H}_{6}$

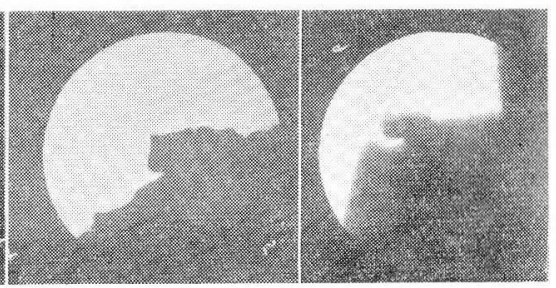

(b) $\mathrm{CO}_{2}$ (c)
Photo. 2 The Electron Micrographs of the Carbon Surface $(\times 2600)$ 


\section{4. 結言}

以上述べたように電話機用炭素粉として最も䢩当と思

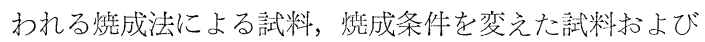
種々の寿命試験を行なった試料について感度，抵抗偭， 接触角，顕微鏡による表面状態等について比較検討した 結果（i）機械的衝撃及び電気的衝撃により生じた欠䧩 (ii）酸化及び煤状炭素の付着による凹凹（iii）水分の吸 着，浸水その他により生じた不純物による表面層等々の 增大は炭素粉の感度をいちじるしく低下させる。

換言すると炭素粉は動き易い粒度，形であると共に細 かくみると表面は緻密平滑で清浄であることが良感度で
あるための必要条件であることが明らかになった。

終りに剧指導を賜わった名古屋大学野昍稻:教授並び に当社，小林正次専䂆，不川義興基礎研究所與，森生進 基璴研究所長代理の諸博士および类験に協力下された根 本末吉，平野一郎，渡辺筧の諸氏に感謝致します。

\section{交献}

1）伊藤，杉本，山崎：研究実用化報告 Vol. 3, No. 1, 1954

2）久保田：炭素, Vol. 8, No. 1, 1960

3）植松：日本機械学会誌，Jan. 1953

$(37-12-12)$

\section{書 評}

\section{A.R. Ubbelohde and F.A. Lewis: Graphite AND ITs CRYsTAL Compounds Oxford University Press 1960, 217 pages, 35 s.}

炭素材料の研究は科学のいろいろな分野とつながりが あるので unique な著書をつくることは仲々むづかし い。Old carbon men には Mantel の Industrial Carbon が一般向の手引書として親しまれて来たが既に版も古 く, basic な事柄については食い足りない感じを抱かれ る向も少なくないであろう。その点本書は問題を一応表 題のように限定した上で，ガッチリと書き上げた基礎科 学の本である。しかし却ってその故に, 生産現場で活動 している人々にも適当な刺げきと最新の知見を供給する かつ好な良書となっているように思う。

著者 Ubbelohde 教授は英国の著名な化学者の 1 人で あるが, Carbon Science の分野でも多くの業績があり, その快偉な風丰と共に一方の旗頭として知られている。 内容は九つの章から成り，第 5 章までが黒鉛，以下がそ の結晶化合物という仕分けで，どちらかというと広い意 味で電子の干与する物性一般（化学的問題もふくめて） とその解釈に力点がおかれている。これは 1950 年以降
の one decade に著しく発展した分野で，著者自身も最 も得意とする領域であってみれば当然の結果であろう。 記述は至って平易で徒らにこむつがい話は入って来な い。扱われている問題は近代的なものであるが，200 頁 足らずの本文中に図表，写真を多く聥入して，誰にもの みこめるようによく工夫して書かれている。多少難をい えば Mechanical propertiesに関する部分は簡略に過ぎる きらいもないではないが，これは microscopic な機構の 解釈がほとんど目鼻のついていない状況なので，余り著 者の興味をひきつけなかったのか子知れない。

英文も平易であるし，邦貸で 2000 円足らずという価 格も好感が持てる。なるべく多くの方に，一つラクな気 持で先ずひもといて見られるようにおすすめしたい。又 赤松教授を始め相当数の日本人の論文が方々に referさ れていることも，つけ加えておいてよいことであろう。

(日大理工 都竹卓郎) 